\title{
Frequent Allocation of Rotationally Grazed Dairy Cows Changes Grazing Behavior and Improves Productivity
}

\author{
P. A. Abrahamse, ${ }^{* 1}$ J. Dijkstra, ${ }^{*}$ B. Vlaeminck, $\dagger$ and S. Tamminga* \\ ${ }^{*}$ Animal Nutrition Group, Wageningen Institute of Animal Sciences, Wageningen University, \\ PO Box 338, $6700 \mathrm{AH}$ Wageningen, the Netherlands \\ †Laboratory for Animal Nutrition and Animal Product Quality, Ghent University, Proefhoevestraat 10, 9090 Melle, Belgium
}

\begin{abstract}
Twenty Holstein cows were blocked in 2 groups according to milk yield to evaluate the effect of frequency of allocation to new grazing plots on pasture intake, grazing behavior, rumen characteristics, and milk yield. The 2 treatments, daily allocation to 0.125 -ha plots (1D) or allocation every $4 \mathrm{~d}$ to 0.5 -ha plots (4D) of Lolium perenne L., were tested in a randomized block design (2 rotations with 3 or 4 measuring periods of $4 \mathrm{~d}$ each) with mixed model analysis accounting for repeated measures. There were no differences in the chemical composition of offered pasture and in pasture dry matter intake (DMI) between 1D and 4D. However, an interaction between treatment and rotation indicated a difference in pasture DMI between treatments during the first rotation (4D, 16.5 vs. $1 \mathrm{D}, 18.3 \mathrm{~kg} / \mathrm{d}$ ) but not during the second rotation ( $4 \mathrm{D}, 15.0$ vs. $1 \mathrm{D}, 14.7$ $\mathrm{kg} / \mathrm{d}$ ), possibly a result of a greater pasture mass in the first rotation. Grazing time (average $562 \mathrm{~min} / \mathrm{d}$ ) and ruminating time (average $468 \mathrm{~min} / \mathrm{d}$ ), observed using IGER graze recorders, were similar between treatments, but grazing time increased numerically (549 to $568 \mathrm{~min} / \mathrm{d}$ ), and ruminating time decreased linearly ( 471 to $450 \mathrm{~min} / \mathrm{d}$ ) within periods in the $4 \mathrm{D}$ treatment. Mean rumen $\mathrm{pH}(6.16$ vs. 6.05$)$ and rumen $\mathrm{NH}_{3}-\mathrm{N}$ concentration ( 113.7 vs. $90.1 \mathrm{mg} / \mathrm{L}$ ) were higher in $4 \mathrm{D}$ than in 1D, and total volatile fatty acid (VFA) concentrations did not differ. Molar proportions of VFA, except butyrate, differed between treatments, causing the nonglucogenic to glucogenic VFA ratio to be greater in $4 \mathrm{D}$ than in $1 \mathrm{D}$. Within days in the $4 \mathrm{D}$ treatment, the molar proportion of acetate increased and those of all other VFA decreased linearly. Rumen $\mathrm{NH}_{3}-\mathrm{N}$ concentration within the $4 \mathrm{D}$ treatment declined quadratically from $170.3 \mathrm{mg} / \mathrm{L}$ on d 1 to $80.7 \mathrm{mg} / \mathrm{L}$ on $\mathrm{d} 4$. In contrast to rumen $\mathrm{NH}_{3}-\mathrm{N}$ concentration, milk urea content did not differ between treatments, but decreased quadratically
\end{abstract}

Received August 6, 2007.

Accepted January 6, 2008.

${ }^{1}$ Corresponding author: Sander.Abrahamse@wur.nl from $\mathrm{d} 1$ to 4 in the 4D treatment (from 26.7 to 20.7 $\mathrm{mg} / \mathrm{dL}$ ). Mean fat- and protein-corrected milk was greater in $1 \mathrm{D}$ than in $4 \mathrm{D}$ (23.5 vs. $22.8 \mathrm{~kg} / \mathrm{d})$, mainly due to a difference in milk yield (24.5 vs. $23.7 \mathrm{~kg} / \mathrm{d}$ ). Fat and protein content were slightly lower in the 1D than in the $4 \mathrm{D}$ treatment (3.66 vs. $3.76 \%$ and 3.28 vs. $3.34 \%$, respectively). This study confirmed that increasing pasture allocation frequency from once every $4 \mathrm{~d}$ to every day improved milk production in grazing dairy cows, especially when offered pasture was high.

Key words: dairy cow, grazing behavior, rumen fermentation, milk yield

\section{INTRODUCTION}

In grazing systems, pasture DMI is often insufficient to achieve high milk yield (Bargo et al., 2003). Grazing management may influence grazing behavior and thus influence pasture DMI. Grazing is defined as "the taking of a succession of bites from the surface of the sward, with the depth of each bite into the sward being influenced by the vertical distribution of sward characteristics such as live and dead material and of morphological components such as leaves and pseudostems" (Illius and Gordon, 1987). Pasture DMI of grazing cows is the product of total grazing time $(\mathbf{G T}, \mathrm{min} / \mathrm{d})$ and intake rate (IR, g/min of grazing), with IR the product of bite rate (BR, bites/min) and bite mass (BM, g of DM/bite). Important factors influencing BM in grazing cows are sward surface height (SSH) and the mass of pasture (PM) offered (Allden and Whittaker, 1970). The effect of SSH on BM is curvilinear, with successively smaller increments in BM for each increment in SSH (Chilibroste, 2005).

Pasture DMI is related to the chemical composition of pasture, which is affected by, among others, days of regrowth, season, and time of day. Pasture DMI increased when a high-sugar and low-NDF ryegrass cultivar was offered to zero-grazed cows in early lactation (Moorby et al., 2006). In contrast, cultivars with elevated water-soluble carbohydrate content did not consistently result in greater pasture DMI in grazing dairy 
cattle (Tas et al., 2006) or in zero-grazed dairy cattle (Miller et al., 2001; Taweel et al., 2005).

Variation in chemical composition of pasture also occurs within the vertical distribution of pasture offered to cows as the proportion of lamina material decreases, and the proportion of stem and dead material increases as the animal grazes progressively down through the sward. Delagarde et al. (2000) showed an enrichment of DM and structural carbohydrates in the lower layers of the sward whereas the upper layers were enriched in CP and sugar. Thus, due to modified morphology and chemical composition, successive defoliations of the same area will result in a reduction of BM, IR, and $\mathrm{CP}$ and sugar content, but an increase in structural carbohydrate content of the material ingested. Such differences in pasture composition may be involved in the control of short-term daily pasture intake through effects on the concentrations of fermentation end products, rumen fill, and clearance rate of feed from the rumen, as these have been suggested as a combination of signals that control intake (Forbes, 1996). Indeed, an increased GT and decreased BM on short swards as compared with longer swards, as well as increased rumen fill and increased pool sizes of fermentation end products, were found after longer regrowth of pasture (Chilibroste et al., 2000). Under a continuous stocking system, BR, chewing rate, and BM were increased as the day progressed, showing the potential to maximize intake through intake behavior, whereas rumen fermentation end products did not play an important role in initiating or terminating a grazing bout (Taweel et al., 2004).

Different rotational grazing strategies might result in changes in grazing behavior by affecting the chemical and morphological characteristics of the sward within and between days. It has been postulated that these rotational grazing systems result in a more efficient utilization of grassland, increase pasture DMI, and enhance productivity (Holecheck et al., 1995). In various countries, rotational grazing involves access of cows to fresh pasture once or twice daily to benefit from assumed increased productivity on fresh pasture. In other rotational grazing systems, fresh pasture is provided after several days to save on labor and fencing costs. However, scientific evidence on the effects of allocation frequency is scarce, and Parsons and Chapman (2000) even argued that effects of differences in grazing management on production are more imagined than real. Daily strip grazing resulted in greater milk yield per hectare compared with paddock grazing, although there were no differences in milk yield per cow per day (Kuusela and Khalili, 2002). In contrast, Dalley et al. (2001) found a decrease in milk yield for frequently allocated cows ( 6 times daily vs. once daily) despite the numerically greater pasture DMI.

The objective of this experiment was to determine the influence of 2 grazing systems (once daily vs. once every $4 \mathrm{~d}$ reallocating to a fresh plot) on pasture DMI, grazing behavior, rumen characteristics, and milk yield in grazing dairy cows.

\section{MATERIALS AND METHODS}

\section{Experimental Design and Treatments}

The experiment was undertaken between July 6 and August 9, 2004, after approval by the Institutional Animal Care and Use Committee of Wageningen University. The study was conducted as paired comparisons in a randomized block design with repeated measures. After adaptation to grazing during $3 \mathrm{wk}, 2$ groups of 10 dairy cows were assigned to their respective treatments and adapted to these treatments during $4 \mathrm{~d}$. The treatments, reallocation after morning milking every day (1D) to a fresh 0.125 -ha plot or every $4 \mathrm{~d}$ to a 0.5 ha plot (4D), were repeated during 2 rotations with 4 periods of $4 \mathrm{~d}$ in the first rotation and 3 periods of $4 \mathrm{~d}$ in the second rotation. Water was available ad libitum.

\section{Pasture}

A uniform stand of perennial ryegrass (Lolium perenne L., cultivar Havera, 70:30 mixture of tetraploid and diploid), established in August 2003, was used during the experiment. The fertilizer application rates were $78 \mathrm{~kg}$ of N/ha in spring, $52 \mathrm{~kg}$ of N/ha before the first rotation, and $54 \mathrm{~kg}$ of N/ha before the second rotation. The paddock was divided into 10 plots of 0.5 ha that were stepwise cut ( 2 plots every $4 \mathrm{~d}$ ). For treatment 1D, half of the plots were then split into 4 subplots of 0.125 ha. This procedure was carried out to have approximately equal DM offered per day after $25 \mathrm{~d}$ of regrowth preceding the first rotation, and $18 \mathrm{~d}$ of regrowth preceding the second rotation.

Pasture mass offered was estimated using a method comparable to the double sample technique described by Chilibroste et al. (2000). Sward surface height was measured in 25 quadrats $(0.5 \times 0.5 \mathrm{~m})$ with a rising plate meter (weight: $350 \mathrm{~g}$, diameter: $0.5 \mathrm{~m}$, standing pressure ca. 17.5 N/m²; Eijkelkamp, Giesbeek, the Netherlands), and PM above $4 \mathrm{~cm}$ from ground level was determined. The $\mathrm{r}^{2}$ of the regression of PM against SSH was 0.52 and 0.92 for the first and second rotation, respectively. Pasture mass per day was calculated using approximately 20 and $40 \mathrm{SSH}$ measurements per milking for $1 \mathrm{D}$ and $4 \mathrm{D}$, respectively. 


\section{Animals}

Twenty Holstein cows, of which 6 were previously fitted with a rumen cannula (10 cm i.d.; Bar Diamond Inc., Parma, ID) in the dorsal sac, were paired by parity, DIM, and milk yield during the adaptation period and randomly assigned to the treatments. Rumen-cannulated animals were paired and assigned similarly. At the start of the experiment, cows produced $22.4 \pm 0.6$ $\mathrm{kg}$ of milk/d (values expressed as means $\pm \mathrm{SE}$ ), and were $178 \pm 12$ DIM; BW was $533 \pm 14 \mathrm{~kg}$, and BCS was $2.5 \pm 0.1$ (recorded on a 5 -point scale). These variables were similar between treatments.

Cows were milked twice daily at 0600 and $1600 \mathrm{~h}$ using a mobile milking parlor and individual milk yield was recorded throughout the experiment. Individual milk samples were collected at each milking and stored no longer than $4 \mathrm{~d}$ in a refrigerator at $4^{\circ} \mathrm{C}$ using sodium azide and bronopol as preservative. Fat, protein, and lactose contents were determined according to ISO 9622 (Melkcontrolestation, Zutphen, the Netherlands; ISO, 1999c), and milk urea was determined using the $\mathrm{pH}$ difference technique (ISO 14637; ISO, 2004). Fat- and protein-corrected milk (FPCM) yield (kg/d) was calculated as $[(0.337+0.116 \times$ fat $\%+0.06 \times$ protein $\%) \times$ milk yield (kg/d; CVB, 2007)]. Cows received a concentrate (Table 1) with alkanes (2.72 $\mathrm{kg}$ of $\mathrm{DM} / \mathrm{d})$ in 2 equal portions during milking throughout the experiment starting $14 \mathrm{~d}$ before the start of the experiment. The alkane dotriacontane $\left(\mathrm{C}_{32}\right)$ was dissolved over cellulose powder (arbocel; 1:10) and added to the concentrate feed before pelleting. Daily alkane supplementation was 949 $\mathrm{mg} / \mathrm{d}$ and concentrate orts were collected daily. Intake of concentrate $(2.71 \mathrm{~kg}$ of $\mathrm{DM} / \mathrm{d})$ was almost complete. Pasture DMI was estimated as described by Taweel et al. (2006). In contrast to the methodology described by Taweel et al. (2006), pasture and feces were sampled twice daily around milking throughout the experiment, and 4 concentrate samples were taken. Pasture and concentrate samples were pooled per treatment per rotation and fecal samples were pooled per animal per rotation. Samples were stored at $-20^{\circ} \mathrm{C}$, freeze-dried, and ground to pass through a $1-\mathrm{mm}$ sieve before alkane analysis.

\section{Pasture and Concentrate Sampling}

During every milking, representative samples from the pasture were randomly collected from both treatments at $4 \mathrm{~cm}$ above ground level and oven-dried for $24 \mathrm{~h}$ at $70^{\circ} \mathrm{C}$. Similarly, residual pasture was randomly sampled and dried immediately after cows were allocated to a new plot. At the end of the experiment, samples were pooled into 2 samples in 1D (offer and residual) and 5 samples in $4 \mathrm{D}$ (d 1, 2, 3, and 4 and residual)
Table 1. Ingredient and chemical composition of the concentrate

\begin{tabular}{|c|c|}
\hline Item & Concentrate \\
\hline \multicolumn{2}{|l|}{ Ingredient, $\mathrm{g} / \mathrm{kg}$} \\
\hline Barley & 15.0 \\
\hline Corn & 23.2 \\
\hline Beet pulp & 22.0 \\
\hline Soyhulls & 19.0 \\
\hline Soy & 7.0 \\
\hline Coconut expeller & 5.0 \\
\hline Molasses & 6.0 \\
\hline Vitamin mineral premix & 1.5 \\
\hline Sodium chloride & 0.2 \\
\hline Calcium carbonate & 0.6 \\
\hline Magnesium oxide $85 \%$ & 0.2 \\
\hline Alkane + arbocel mix & 0.4 \\
\hline \multicolumn{2}{|c|}{ Chemical composition, $\mathrm{g} / \mathrm{kg}$ of DM } \\
\hline $\mathrm{DM}, \mathrm{g} / \mathrm{kg}$ & 906 \\
\hline $\mathrm{OM}$ & 928 \\
\hline $\mathrm{CP}$ & 144 \\
\hline Crude fat & 15 \\
\hline Sugars & 112 \\
\hline Starch & 223 \\
\hline NDF & 280 \\
\hline $\mathrm{ADF}$ & 188 \\
\hline $\mathrm{ADL}^{1}$ & 12 \\
\hline $\mathrm{NE}_{\mathrm{L}}{ }^{2,3} \mathrm{MJ} / \mathrm{kg}$ of $\mathrm{DM}$ & 7.5 \\
\hline DVE $^{3,4}$ & 107 \\
\hline $\mathrm{OEB}^{3,5}$ & -18 \\
\hline
\end{tabular}

${ }^{1}$ Acid detergent lignin.

${ }^{2}$ Calculated with VEM system (Van Es, 1975).

${ }^{3}$ Value provided by the feed manufacturer (Research Diet Services, Wijk bij Duurstede, the Netherlands).

${ }^{4}$ Intestinal digestible protein (Tamminga et al., 1994).

${ }^{5}$ Degraded protein balance (Tamminga et al., 1994).

per rotation. Also, 4 representative concentrate samples were taken, dried, and pooled per rotation. Pasture and concentrate samples were ground to pass through a 1-mm sieve and analyzed for DM, inorganic matter (ash), $\mathrm{CP}(\mathrm{N} \times 6.25)$, crude fat, $\mathrm{NDF}, \mathrm{ADF}$, acid detergent lignin (ADL), and sugars. The DM content was determined by drying at $103^{\circ} \mathrm{C}$ (ISO 6496; ISO, 1999a) and ash content was determined by combustion at $550^{\circ} \mathrm{C}$ (ISO 5984; ISO, 2002). The Berntrop-method (ISO 6492; ISO, 1999b) was used to determine crude fat, and $\mathrm{N}$ was determined according to the Kjeldahl method with $\mathrm{CuSO}_{4}$ as the catalyst (ISO 5983; ISO, 1997). Neutral detergent fiber was determined according to a modified method of Van Soest et al. (1991) with additional incubations in alpha amylase and protease as described by Goelema et al. (1998). Contents of $\mathrm{ADF}$ and ADL were determined according to Van Soest (1973). Sugar analysis was carried out as described by Van Vuuren et al. (1993) using a $40 \%$ ethanol solution. Modifications to this method were as follows: 1) after hydrolysis, $0.25 M \mathrm{~K}_{4} \mathrm{Fe}(\mathrm{CN})_{6} \cdot 3 \mathrm{H}_{2} \mathrm{O}$ (Carrez I) and 0.5 $M \mathrm{Zn}\left(\mathrm{C}_{2} \mathrm{H}_{3} \mathrm{O}_{2}\right)_{2} \cdot 2 \mathrm{H}_{2} \mathrm{O}$ (Carrez II) were used to clarify the solution, which was filtered (5951/2, $150 \mathrm{~mm}$ diameter, Whatman Sleicher \& Schuell, Dassel, Germany); 
2) dilution depended on estimated concentrations of sugars, which were dissolved in 10-fold lower concentrations of $\mathrm{CuSO}_{4} \cdot 5 \mathrm{H}_{2} \mathrm{O}, \mathrm{Na}_{2} \mathrm{CO}_{3} \cdot 10 \mathrm{H}_{2} \mathrm{O}$ and neocuproine than described by Van Vuuren et al. (1993); 3) concentrations were measured using a spectrophotometer (model Du 530, Beckman Coulter, Fullerton, CA) at $460 \mathrm{~nm}$ and 4) concentrations were estimated by calibration using a standard curve ranging from 10 to $100 \mathrm{mg}$ of glucose/L.

During 2 periods per rotation, samples from the pasture were taken during milking at $4 \mathrm{~cm}$ above ground level and pooled per day to determine pasture morphology. Pasture material was distinguished into leaf blade, pseudostem (split at the ligule of each leaf), stem, and dead material (all material without green color).

\section{Grazing Behavior}

Grazing behavior of 4 cows per treatment was observed using Institute of Grassland and Environmental Research (IGER) solid-state automatic behavior recorders (Ultra Sound Advice, London, UK; Rutter et al., 1997). Jaw recorders were fitted to the cows after the morning milking and removed after the next morning milking. Recordings were obtained on $\mathrm{d} 1$ and 3 in 1D and every day in $4 \mathrm{D}$. The data were analyzed with the Graze Data Analyses Program (version 8.0, IGER, Devon, UK), identifying jaw movements and different behaviors (grazing, ruminating, idling; Rutter, 2000). Bite mass (per cow per rotation) was calculated as pasture DMI divided by the average number of bites per day.

\section{Rumen Measurements}

During the last 3 periods of the first rotation and during all periods of the second rotation, rumen fluid samples were taken after every milking from the $6 \mathrm{ru}$ men-cannulated animals. Equal amounts of rumen fluid were collected from the front and middle of the ventral sac and from the cranial sac using a solid, perforated plastic tube ( $85 \mathrm{~cm}$ long, $2.5 \mathrm{~cm}$ in diameter). The $\mathrm{pH}$ was measured immediately using an electronic $\mathrm{pH}$ meter ( $\mathrm{pH}$ electrode HI 1230, Hanna Instruments B.V., IJsselstein, the Netherlands). A duplicate sample was taken and either acidified with phosphoric acid or with trichloroacetic acid, and stored at $-20^{\circ} \mathrm{C}$ pending VFA and $\mathrm{NH}_{3}-\mathrm{N}$ analysis, respectively, as described by Taweel et al. (2005).

\section{Statistical Analysis}

All statistical analyses were carried out by ANOVA using the PROC MIXED procedure of SAS (version 9.1;
SAS Inst. Inc., Cary, NC). Multiple measurements per animal cannot be regarded as independent units of observations (Littell et al., 1998). Therefore, repeatedmeasures ANOVA was performed on all data except for pasture chemical composition, with day as the repeated subject. A first-order autoregressive covariance structure [AR(1)] fitted the data best and was used to account for within-cow variation. To determine time-dependent changes, orthogonal contrasts were used. Data are presented similarly for all variables, with treatment means for $1 \mathrm{D}$ and $4 \mathrm{D}$ and for the 4 different days per period within 4D, SEM for the treatment effects and for the effects of day within $4 \mathrm{D}$, and $P$-values for treatment effects and linear and quadratic effects of day within $4 \mathrm{D}$. The only exception is the chemical and morphological composition of the pasture offered (Table 2) because pasture samples were pooled per rotation for $1 \mathrm{D}$. Therefore the treatment effect was tested after calculating the average composition per rotation in $4 \mathrm{D}$. Differences were considered significant at a probability of $P<0.05$, and posthoc analyses were carried out using the Tukey test to test pairwise comparisons. When interactions were not significant $(P>0.05)$, they were excluded from the model.

Pasture Morphological and Chemical Composition. The average chemical and morphological composition of offered pasture per rotation per treatment was analyzed with treatment, rotation, and sample (offer or residual) as fixed factors. Time of sampling (morning vs. evening milking) was also included in the model for pasture DM content. The interaction between sample and treatment was not significant $(P>0.05)$ and therefore excluded from the model. The effect of day on pasture chemical composition was further analyzed for the 4D treatment with rotation and day as fixed factors.

Pasture mass and SSH data were calculated per treatment per day. The statistical model included treatment, rotation, day nested within treatment, and the interaction between treatment and rotation as fixed factors. Pasture DMI was analyzed similar to the analysis on the chemical composition of pasture, although the fixed factor cow and the interaction between treatment and rotation were included in the model.

Grazing Behavior. Grazing behavior variables were analyzed per day ( $24 \mathrm{~h}$ ) as well as after separating the data into the period between morning and evening milking (10 h; between 0600 and 1600 h; AM-PM) and between evening and morning milking ( $14 \mathrm{~h}$; between 1600 and 0600 h; PM-AM). Grazing behavior was analyzed with treatment, rotation, and day nested within treatment as fixed factors using the repeated-measures procedure with day as the repeated variable. Bite mass was analyzed with rotation and treatment as fixed fac- 
Table 2. Chemical and morphological composition of pasture of dairy cows allocated every day (1D) or every $4 \mathrm{~d}(4 \mathrm{D})$ to a new plot

\begin{tabular}{|c|c|c|c|c|c|c|c|}
\hline \multirow[b]{2}{*}{ Item } & \multicolumn{2}{|c|}{$1 \mathrm{D}$} & \multicolumn{2}{|c|}{$4 \mathrm{D}$} & \multirow[b]{2}{*}{ SEM } & \multicolumn{2}{|c|}{$P$-value } \\
\hline & Offer & Residual & Offer & Residual & & Treatment & Offer vs. residual \\
\hline \multicolumn{8}{|c|}{$\begin{array}{l}\text { Chemical composition, } \\
\mathrm{g} / \mathrm{kg} \text { of DM }\end{array}$} \\
\hline $\mathrm{DM}, \mathrm{g} / \mathrm{kg}$ & 169.1 & 192.5 & 169.8 & 181.6 & 5.43 & 0.455 & 0.036 \\
\hline $\mathrm{OM}$ & 892.8 & 886.5 & 892.0 & 885.5 & 0.60 & 0.365 & 0.005 \\
\hline $\mathrm{CP}$ & 147.7 & 127.7 & 148.5 & 130.5 & 2.62 & 0.655 & 0.014 \\
\hline Crude fat & 28.4 & 22.9 & 27.4 & 24.2 & 0.53 & 0.877 & 0.010 \\
\hline $\mathrm{NDF}$ & 454.4 & 501.2 & 464.3 & 497.2 & 3.09 & 0.546 & 0.003 \\
\hline $\mathrm{ADF}$ & 273.3 & 296.8 & 279.8 & 299.9 & 2.12 & 0.205 & 0.005 \\
\hline $\mathrm{ADL}^{1}$ & 17.2 & 21.7 & 18.0 & 21.9 & 0.72 & 0.650 & 0.026 \\
\hline Sugars & 154.5 & 134.2 & 153.1 & 136.9 & 1.29 & 0.733 & 0.002 \\
\hline \multicolumn{8}{|c|}{ Morphological composition } \\
\hline Leaf, \% & 68.7 & 49.5 & 65.7 & 52.5 & 1.52 & 1.000 & 0.005 \\
\hline Pseudostem, \% & 21.4 & 35.7 & 22.4 & 31.8 & 1.54 & 0.556 & 0.012 \\
\hline Stem, \% & 5.7 & 2.9 & 6.3 & 5.4 & 0.60 & 0.178 & 0.123 \\
\hline Dead material, \% & 4.1 & 11.9 & 5.6 & 10.3 & 0.77 & 0.977 & 0.010 \\
\hline
\end{tabular}

${ }^{1}$ Acid detergent lignin.

tors using the repeated measures procedure with day as the repeated variable.

Rumen Fluid. The rumen fluid variables were tested with treatment, rotation, time of sampling (during morning or evening milking) and day nested within treatment as fixed variables, using the repeated-measures procedure with day as the repeated variable.

Milk Yield and Composition. Before statistical analysis, milk composition was calculated per day as the weighted average of evening and morning samples following allocation to a new plot. The model contained the fixed effects of treatment, rotation, and day nested within treatment using the repeated measures procedure, with day as the repeated variable. The mean values of the tested variables in the last $18 \mathrm{~d}$ of the adaptation period before cows were assigned to their respective treatment were used as a covariate in the model.

\section{RESULTS}

\section{Pasture}

Pregrazing chemical and morphological composition of the pasture was similar between treatments, but all variables except the percentage of stem were different between the offered and residual pasture (Table 2). Because there was no interaction between treatment and sample (offer or residual), the differences between days in 4 D were further studied. Crude protein $(P=0.005)$ and sugars (trend, $P=0.080$ ) content decreased quadratically and NDF content increased quadratically $(P=0.003$; Figure 1). The content of ADL in NDF between days in $4 \mathrm{D}$ showed a numerical increase on $\mathrm{d} 3$ and 4 . The proportion of leaves decreased quadratically during the $4 \mathrm{~d}$ in $4 \mathrm{D}(P=0.005)$ and the fractions of pseudostem $(P=0.008)$ and stem and dead material $(P=0.050)$ increased quadratically (Figure 2$)$.

Sward surface height offered on d $1(P=1.000)$, PM offered on d $1(P=0.789)$, and residual SSH on d $4(P=$ 0.872) were similar between treatments (results not shown). However, SSH and PM offered were greater, and residual $\mathrm{SSH}$ was lesser in $1 \mathrm{D}$ than in $4 \mathrm{D}$ due to quadratic decreases between days in $4 \mathrm{D}(P<0.05$; Table 3). Pasture DMI did not differ between treatments. Sward surface height and PM offered were greater during the first rotation than the second rotation $(P<$ 0.001). During the first rotation offered SSH and PM were $19.7 \mathrm{~cm}$ and $2,834 \mathrm{~kg}$ of DM/ha, respectively, and during the second rotation SSH and PM were $14.3 \mathrm{~cm}$ and $1,545 \mathrm{~kg}$ of DM/ha, respectively. Although pasture DMI was similar between treatments, an interaction between treatment and rotation was observed $(P=$ 0.025 ), which was caused by an increase of pasture DMI in the $1 \mathrm{D}$ treatment during the first rotation $(4 \mathrm{D}, 16.5$ vs. $1 \mathrm{D}, 18.3 \mathrm{~kg} / \mathrm{d}$ ) but not during the second rotation (4D, 15.0 vs. $1 \mathrm{D}, 14.7 \mathrm{~kg} / \mathrm{d})$.

\section{Grazing Behavior}

Grazing behavior variables were similar between $d$ 1 in $4 \mathrm{D}$ and $\mathrm{d} 1$ in $1 \mathrm{D}$ (results not shown), and similar between treatments with the exception of the number of chews $(P=0.045)$ and the chew rate per day $(P=$ 0.007 ), which were greater in $4 \mathrm{D}$ than in $1 \mathrm{D}$ (Table 4 ). Although similar between treatments, the number of bites, BR, and chews per bolus increased and ruminating time $(\mathbf{R T})$ decreased linearly $(P<0.05)$ from $d 1$ to 4 in the $4 \mathrm{D}$ treatment.

In the AM-PM period, all grazing behavior variables were similar between treatments, with the exception 

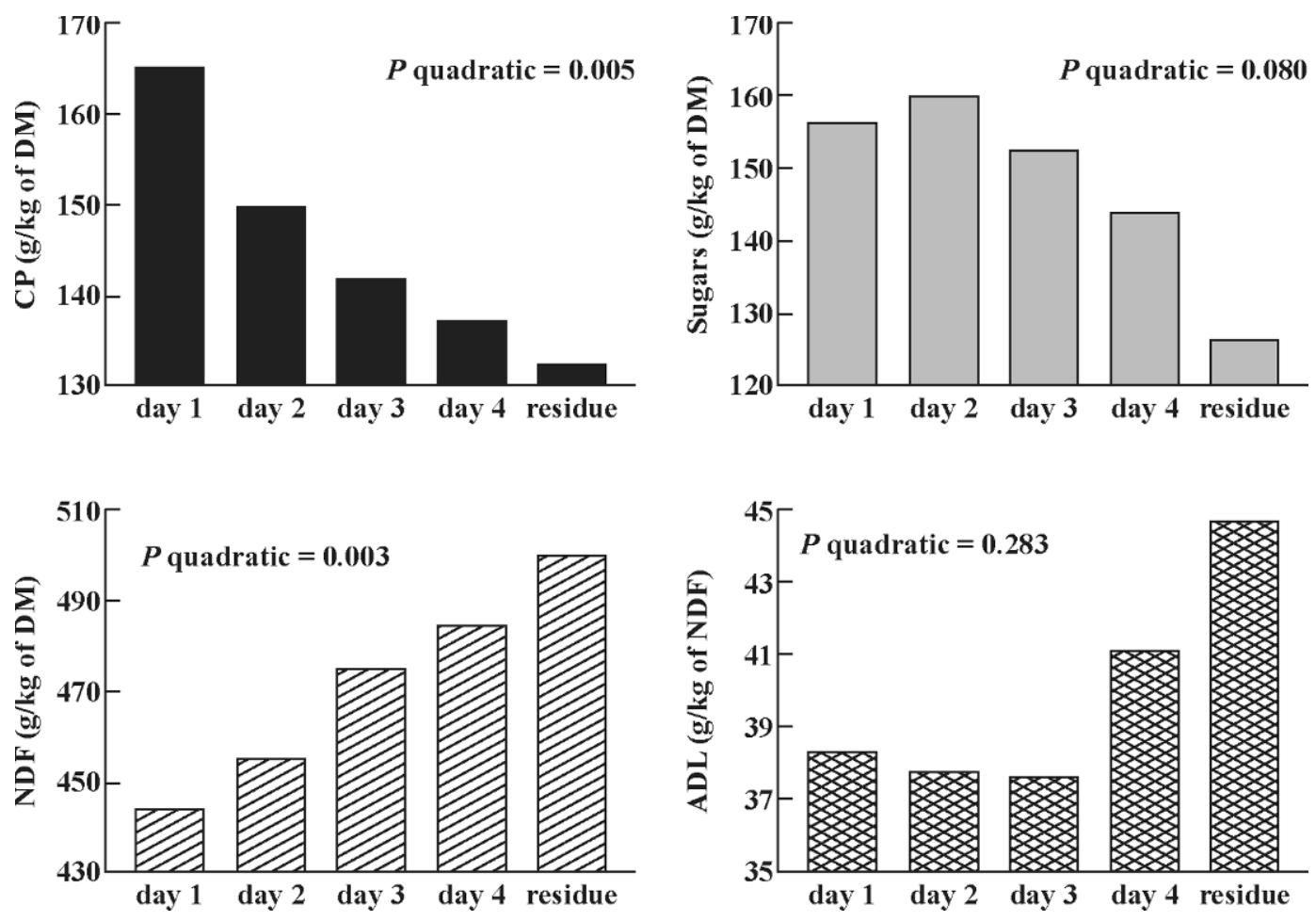

Figure 1. Changes in CP, sugars, NDF and acid detergent lignin (ADL) in NDF content in pasture over days where cows were allocated every $4 \mathrm{~d}$ to a new plot (4D treatment).

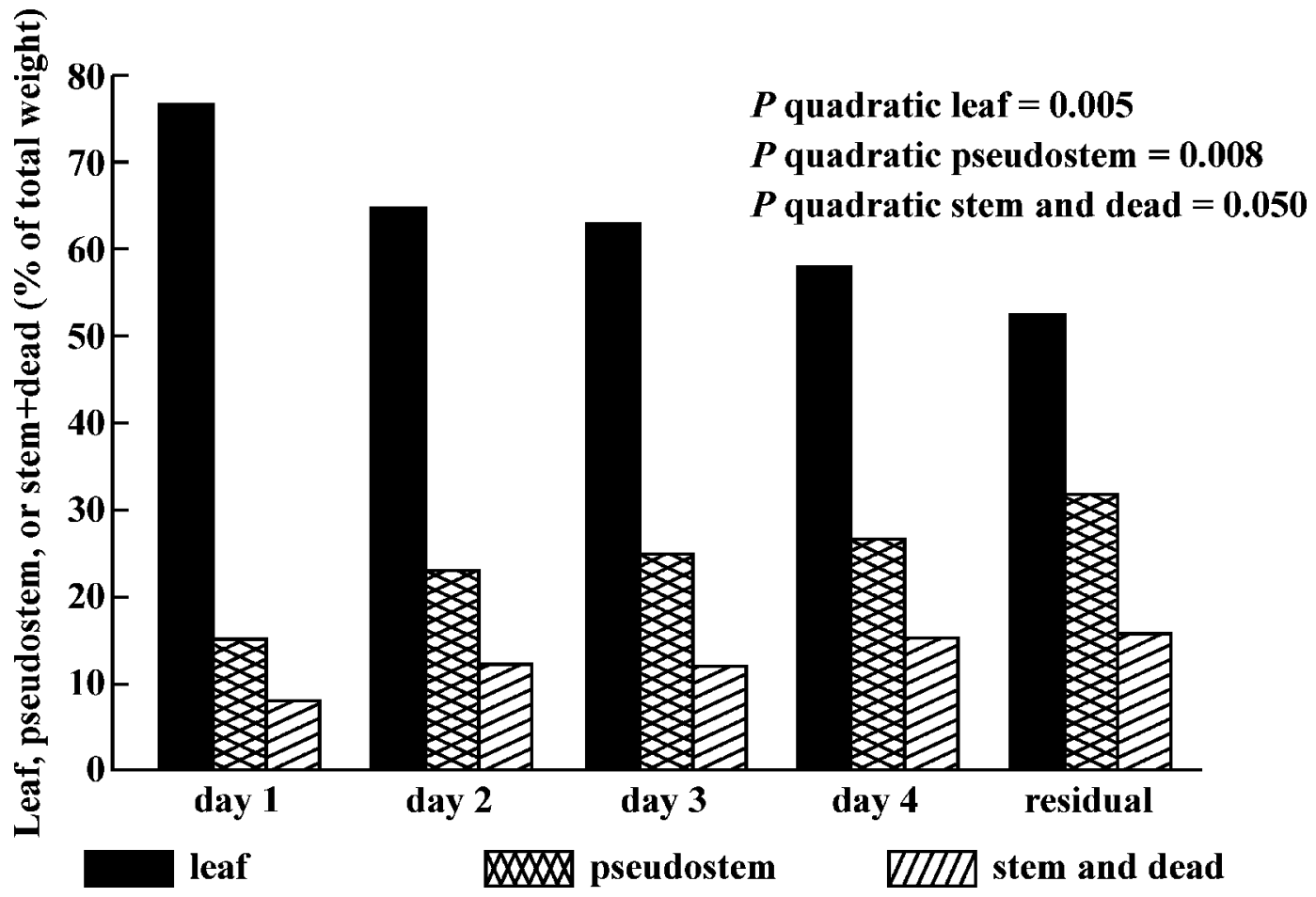

Figure 2. Morphological fractions of pasture when cows were allocated every $4 \mathrm{~d}$ to a new plot (4D treatment). 
Table 3. Mean pasture mass (PM), sward surface height (SSH) of offered pasture, residual SSH, and pasture DMI of dairy cows allocated every day (1D) or every $4 \mathrm{~d}(4 \mathrm{D})$ to a new plot

\begin{tabular}{|c|c|c|c|c|c|c|c|c|c|c|c|}
\hline \multirow[b]{2}{*}{ Variable } & \multirow[b]{2}{*}{$1 \mathrm{D}$} & \multirow[b]{2}{*}{$4 \mathrm{D}$} & \multicolumn{4}{|c|}{ Days in $4 \mathrm{D}$} & \multicolumn{2}{|c|}{ SEM } & \multicolumn{3}{|c|}{$P$-value } \\
\hline & & & d 1 & $\mathrm{~d} 2$ & d 3 & d 4 & $\mathrm{~T}^{1}$ & $\mathrm{D}^{2}$ & $\mathrm{~T}^{1}$ & $\mathrm{D}^{2}$ linear & $\mathrm{D}^{2}$ quadratic \\
\hline $\mathrm{SSH}$ offer, cm & 19.7 & 14.3 & 19.4 & 14.8 & 12.5 & 10.5 & 0.42 & 0.62 & $<0.001$ & $<0.001$ & 0.010 \\
\hline $\mathrm{PM},^{3} \mathrm{~kg}$ of $\mathrm{DM} / \mathrm{ha}$ & 2,600 & 1,779 & 2,485 & 1,784 & 1,523 & 1,323 & 84.4 & 120.2 & $<0.001$ & $<0.001$ & 0.010 \\
\hline Pasture DMI, kg/d & 16.5 & 15.8 & - & - & - & - & 0.65 & - & 0.426 & - & - \\
\hline
\end{tabular}

${ }^{1}$ Treatment.

${ }^{2}$ Day within $4 \mathrm{D}$.

${ }^{3}$ Pasture mass calculated based on plot sizes and using regression formulas between PM (kg of DM/ha) and SSH $(\mathrm{cm})$ per rotation: $\mathrm{PM}=$ $\mathrm{A} \times \mathrm{e}^{(\mathrm{B} \times \mathrm{SSH})}$ where for first rotation: $\mathrm{A}=739.6( \pm 175.5), \mathrm{B}=0.066( \pm 0.013), \mathrm{r}^{2}=0.52, \mathrm{n}=25$; second rotation: $\mathrm{A}=483.9( \pm 50.9), \mathrm{B}=0.079$ $( \pm 0.006), r^{2}=0.92, n=25$.

of $\mathrm{BR}$ being greater in $4 \mathrm{D}$ than in $1 \mathrm{D}(P=0.001)$. Within the $4 \mathrm{D}$ treatment, BR increased linearly $(P=0.021)$. Grazing time and RT AM-PM between days in $4 \mathrm{D}$ showed opposite quadratic effects $(P=0.047$ and $P=$ 0.015 , respectively), resulting in a similar sum of GT and RT between days.

In the PM-AM period, treatment differences were generally more pronounced than in the AM-PM period, with a longer GT $(P=0.020)$, a greater number of bites
$(P=0.013)$ and chews $(P=0.001)$, a greater chew rate $(P=0.002)$, and a lower RT $(P=0.026)$ in $4 \mathrm{D}$ than in 1D. Grazing time as well as the number of bites and BR increased linearly between days in 4D in PM-AM whereas RT decreased linearly $(P<0.05)$. Grazing, ruminating, and idling time in PM-AM between days in $4 \mathrm{D}$, expressed as a percentage of available time, is shown in Figure 3. The linear increase in GT in PM$\mathrm{AM}(P=0.006)$ coincided with a linear decrease in $\mathrm{RT}$

Table 4. Grazing behavior of dairy cows allocated every day (1D) or every $4 \mathrm{~d}$ (4D) to a new plot on a daily basis, between morning and evening milking (0600 to $1600 \mathrm{~h}$; AM-PM) and between evening and morning milking (1600 to $0600 \mathrm{~h}$; PM-AM)

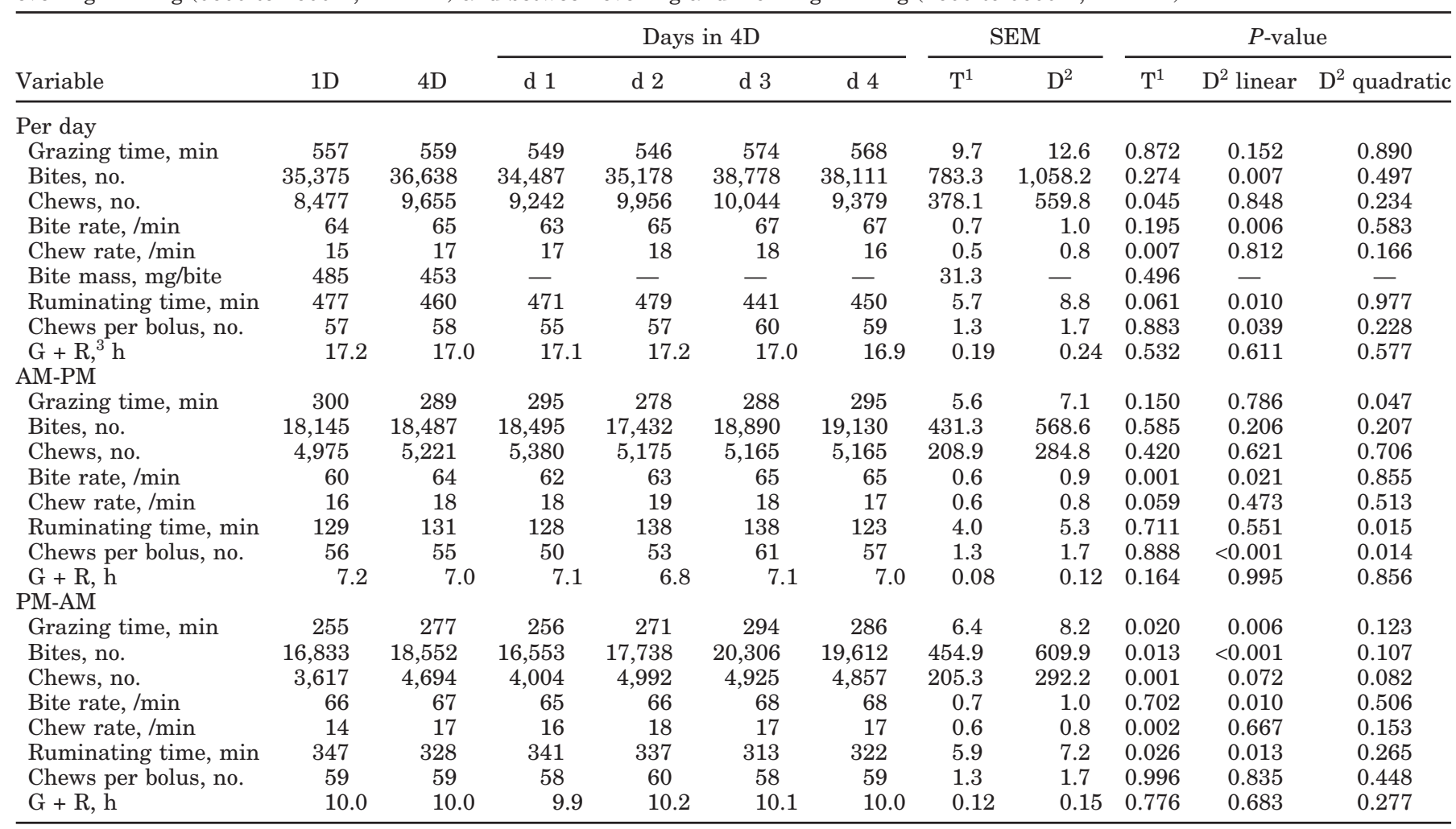

${ }^{1}$ Treatment.

${ }^{2}$ Day within $4 \mathrm{D}$.

${ }^{3} \mathrm{G}+\mathrm{R}$ is the sum of grazing time and ruminating time. 


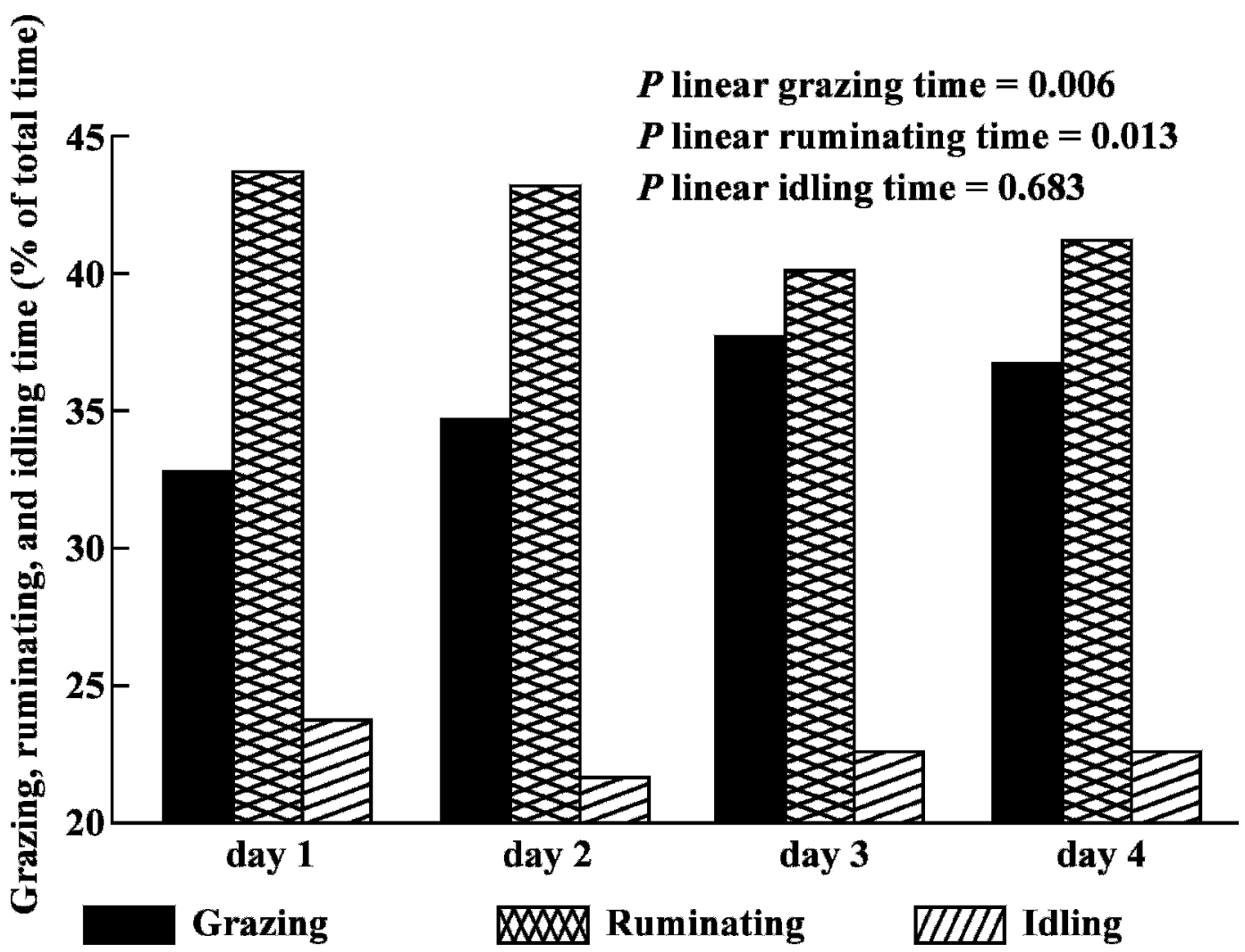

Figure 3. Grazing, ruminating, and idling time per day when cows were allocated every $4 \mathrm{~d}$ to a new plot (4D treatment) as percentage of time between evening and morning milking (1600 to $0600 \mathrm{~h}$; PM-AM).

$(P=0.013)$, while idling remained unaltered in time, in line with the sum of GT and RT (Table 4).

\section{Rumen Variables}

Means per day were similar between days in 1D for all rumen variables except mean molar proportion of isovalerate, which decreased between days in $1 \mathrm{D}$ with the largest difference being 1.12 vs. $0.90 \%(P=0.018)$. Rumen $\mathrm{pH}$ and $\mathrm{NH}_{3}-\mathrm{N}$ concentration in rumen fluid were greater $(P<0.001)$ in $4 \mathrm{D}$ than in $1 \mathrm{D}$ (Table 5$)$. The concentration of total VFA was similar between treatments $(P=0.324)$, but mean molar proportions of all individual VFA, with the exception of butyrate proportions, were different between treatments. Proportions of acetate and isobutyrate were greater $(P<$ 0.01 ) in $4 \mathrm{D}$, whereas propionate, valerate, and isovalerate were greater in $1 \mathrm{D}(P<0.05)$. These changes in molar proportions of individual VFA resulted in a greater nonglucogenic to glucogenic ratio in $4 \mathrm{D}$ than in 1D $(P=0.003)$. This ratio is calculated as [acetate +2 $\times$ (butyrate + isobutyrate $)+$ valerate + isovalerate $/$ [propionate + valerate + isovalerate].

There were strong day effects in $4 \mathrm{D}$ for all rumen variables. Rumen $\mathrm{pH}$ and nonglucogenic to glucogenic ratio increased linearly, whereas total VFA concentration decreased linearly $(P<0.01)$. The decrease in $\mathrm{NH}_{3}-$ $\mathrm{N}$ was stronger in the first days of the 4-d period resulting in a quadratic effect $(P=0.006)$. During the 4 $\mathrm{d}$ period, molar proportions of acetate increased linearly $(P<0.001)$, whereas the molar proportions of the other VFA decreased linearly $(P<0.05)$.

\section{Milk}

Milk and FPCM yield were greater in 1D than in 4D $(P<0.003$; Table 6$)$. Fat and protein contents in milk were greater in $4 \mathrm{D}$ than in $1 \mathrm{D}(P<0.05)$, whereas milk lactose and urea content, and fat and protein yield were similar between treatments.

Milk production and composition changed during the $4 \mathrm{~d}$ in $4 \mathrm{D}(P<0.01)$ except for lactose content. Milk and FPCM yield increased on d 2 after which they decreased, resulting in a quadratic effect $(P<0.001)$. Milk fat content showed a quadratic effect between days in $4 \mathrm{D}$ with the greatest milk fat content on $\mathrm{d} 1$ and the lowest on $\mathrm{d} 2(P<0.001)$. Milk protein content decreased linearly over time $(P<0.001)$. The decrease in milk urea content was smaller during the last day than at the start of the 4 -d period $(P$ quadratic $=0.005)$. Milk 
Table 5. Rumen $\mathrm{pH}, \mathrm{NH}_{3}-\mathrm{N}$, total VFA (mmol/L), and molar proportions of individual VFA of dairy cows allocated every day (1D) or every $4 \mathrm{~d}(4 \mathrm{D})$ to a new plot

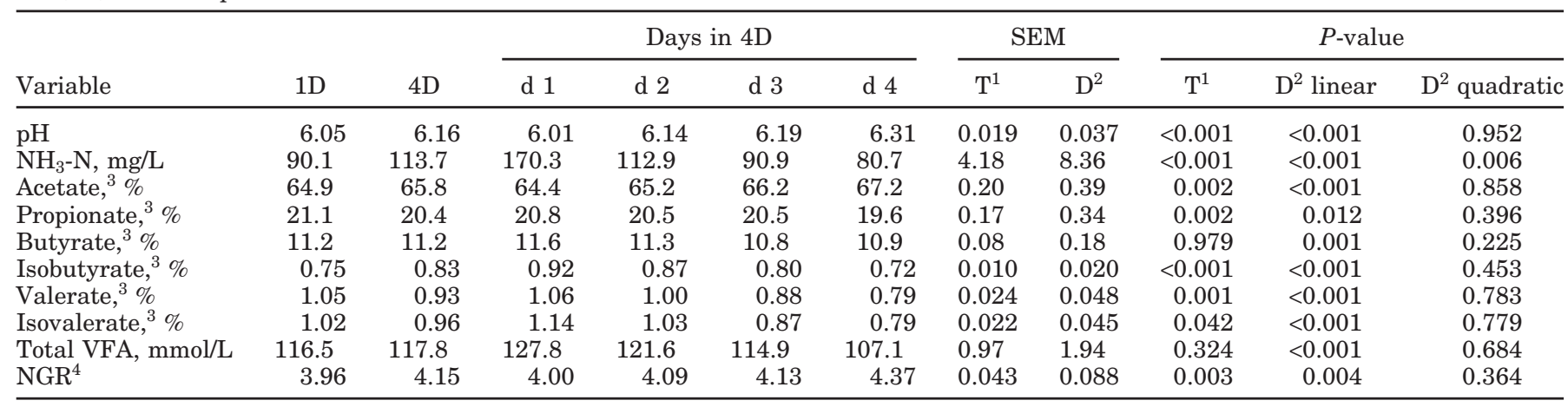

${ }^{1}$ Treatment.

${ }^{2}$ Day within $4 \mathrm{D}$.

${ }^{3}$ Percentage of total VFA.

${ }^{4}$ The nonglucogenic to glucogenic ratio (NGR) was calculated as [acetate $+2 \times($ butyrate + isobutyrate $)+$ valerate + isovalerate]/[propionate + valerate + isovalerate].

fat production per day decreased linearly between days in $4 \mathrm{D}(P<0.001)$, and milk protein production per day showed a quadratic response $(P<0.001)$.

\section{DISCUSSION}

The objective of this experiment was to determine the influence of daily allocation and allocation every $4 \mathrm{~d}$ to new grazing plots on pasture DMI, grazing behavior, rumen characteristics, and milk yield in dairy cows. Frequent allocation of cows to new grazing plots is carried out in grazing management of modern dairy farming in different parts of the world (e.g., Australia, the Netherlands), although very little information is available on the effects of grazing behavior, rumen fermentation, and production. Allocating cows once a day to a fresh plot compared with once every $4 \mathrm{~d}$ in the current experiment resulted in greater milk production and greater DMI if the pasture allowance was large. On the $4 \mathrm{D}$ plots, chemical composition of the pasture and consequently grazing behavior and rumen variables differed greatly across days.

\section{Pasture}

A decrease in SSH between days in 4D (Figure 2), as well as between offered and residual pasture in 1D (Table 2), is related to changes in the morphological fractions and is in line with previous experiments (Wales et al., 1998; Virkajarvi et al., 2002). The resulting changes in proximate chemical composition reflect the greater CP and sugar content and lower concentration of cell wall constituents in leaves than in stems (Delagarde et al., 2000). The increase in ADL in

Table 6. Milk yield and milk composition of dairy cows allocated every day (1D) or every $4 \mathrm{~d}$ (4D) to a new plot

\begin{tabular}{|c|c|c|c|c|c|c|c|c|c|c|c|}
\hline \multirow[b]{2}{*}{ Variable } & \multirow[b]{2}{*}{$1 \mathrm{D}$} & \multirow[b]{2}{*}{$4 \mathrm{D}$} & \multicolumn{4}{|c|}{ Days in $4 \mathrm{D}$} & \multicolumn{2}{|c|}{ SEM } & \multicolumn{3}{|c|}{$P$-value } \\
\hline & & & d 1 & $\mathrm{~d} 2$ & d 3 & d 4 & $\mathrm{~T}^{1}$ & $\mathrm{D}^{2}$ & $\mathrm{~T}^{1}$ & $\mathrm{D}^{2}$ linear & $\mathrm{D}^{2}$ quadratic \\
\hline \multicolumn{12}{|l|}{ Milk yield } \\
\hline $\mathrm{FPCM}^{3}, \mathrm{~kg} / \mathrm{d}$ & 23.5 & 22.8 & 23.0 & 23.6 & 22.8 & 21.8 & 0.17 & 0.23 & 0.003 & $<0.001$ & $<0.001$ \\
\hline \multicolumn{12}{|c|}{ Milk composition } \\
\hline Fat, \% & 3.66 & 3.76 & 3.92 & 3.69 & 3.70 & 3.75 & 0.028 & 0.040 & 0.013 & 0.004 & $<0.001$ \\
\hline Protein, \% & 3.28 & 3.34 & 3.40 & 3.33 & 3.33 & 3.29 & 0.016 & 0.018 & 0.018 & $<0.001$ & 0.157 \\
\hline \multicolumn{12}{|l|}{ Amount } \\
\hline Fat, $\mathrm{g} / \mathrm{d}$ & 892 & 876 & 898 & 898 & 869 & 838 & 9.6 & 12.9 & 0.249 & $<0.001$ & 0.081 \\
\hline Protein, g/d & 796 & 791 & 795 & 825 & 793 & 750 & 6.6 & 8.2 & 0.607 & $<0.001$ & $<0.001$ \\
\hline
\end{tabular}

${ }^{1}$ Treatment.

${ }^{2}$ Day within 4D.

${ }^{3}$ Fat- and protein-corrected milk. 
NDF at d4 (Figure 2) suggests that selection of leafy, high quality pasture must have taken place. This is also indicated by the calculated chemical composition of ingested pasture (data not shown), using the difference in offered and residual PM and their respective chemical compositions. The quality of ingested pasture was better than the quality of PM offered, as CP and sugars content were greater and NDF content was lower.

\section{Grazing Behavior}

Taweel et al. (2006) hypothesized that grazing behavior is influenced by pasture composition. However, tensile strength and grazing behavior did not differ among 4 varieties of perennial ryegrass at similar SSH with varying $\mathrm{NDF}$ and water-soluble carbohydrate contents. Sward surface height is expected to influence grazing behavior through effects on IR and consequently GT (Gibb, 2006). At low SSH levels, dairy cattle compensate for the reduced IR by increasing GT at the expense of RT (Gibb et al., 1996). In the present study, the differences in pasture composition and SSH between days in 4D did not coincide with significant changes in GT, although there was a numerical increase in GT ( $P$ linear $=0.152)$ and a linear decrease in RT between days in $4 \mathrm{D}$ (Table 4). These effects were more profound between evening and morning milking than between morning and evening milking. This observation is possibly related to the crepuscular nature of cows, being most active at sunrise and at sunset and the preference of cows not to graze during the night (Albright, 1993; Rutter, 2006). Besides peaks in grazing behavior at sunrise and sunset, Gibb (2006) described that several smaller meals occur between sunrise and evening milking, alternated with ruminating and resting. After evening milking, the greatest amount of daily pasture intake occurred (Gibb, 2006). This was confirmed with findings of Orr et al. (2001) who found short and fragmented meals during the morning following morning allocation to a fresh plot whereas after evening allocation to a fresh plot, the major grazing meal of the day occurred. Although diurnal patterns in grazing behavior were not studied in the current experiment, it seems likely that changes in GT and RT mainly occurred during the major grazing meal and the longest period of ruminating (being the night), resulting in greater differences between evening and morning milking than between morning and evening milking.

Grazing time, as well as the percentage time spent grazing between evening and morning milking (Figure 3 ) increased over days at the expense of time spent ruminating, but time spent idling was not affected. This is in agreement with Gibb (2006), who emphasized the importance of idling (when the animal is not grazing or ruminating; that is, social interaction and resting) in the total time budget per day.

\section{DMI}

The differences in grazing behavior between days in 4D probably affected pasture DMI in these days. Studies with dosed alkanes showed that some 5 to $6 \mathrm{~d}$ are needed for the fecal alkane concentration to reach equilibrium (Dove and Mayes, 1991). Therefore, pasture DMI was estimated per cow per rotation. Diurnal patterns of fecal $n$-alkane excretion have always been a major concern for variation in marker studies when alkanes are pulse-dosed (Dove and Mayes, 1991). The fecal concentrations of the (natural) odd-chain alkanes tend to be relatively constant, but due to the dosing schedule, diurnal variation in excretion of the dosed even-chain alkane can occur. Therefore, during the current experiment fecal samples from spontaneous defecations during $1 \mathrm{~d}$ in the $1 \mathrm{D}$ group were analyzed to investigate diurnal variation in excretion of the dosed alkane in feces (data not shown). Some variation was found in the concentration of dosed alkane in fecal samples. However, the concentrations of dosed alkane in fecal samples at milking, when fecal samples were taken to determine pasture DMI, were similar to the average concentration of dosed alkane over the day. This implies that there was no effect of diurnal variation in alkane excretion in feces on the estimation of pasture DMI.

Pasture DMI was not estimated per day in 4D using the alkane method. Therefore, the relation between SSH and pasture DMI was used in an attempt to discuss possible effects of the imposed treatment on pasture DMI per day within 4D. Sward surface height and pasture DMI usually show a positive relationship (Gibb et al., 1997), which was also found during this experiment (Figure 4). Pasture DMI per group per day was estimated using offered and residual SSH data to calculate offered and residual PM using the regression formulas between SSH and PM as given in Table 3 . The difference between offered and residual PM was assumed to be consumed by the 10 cows per group. The relation between SSH and pasture DMI in the current experiment showed a strong $\left(r^{2}=0.95\right)$ linear relationship over the range of SSH applied (13.6 to $27.1 \mathrm{~cm}$ ). The relation between SSH and BM is expected to be curvilinear, resulting from successively smaller increments in BM at each increment of SSH (Chilibroste, 2005). Because $\mathrm{BR}$ generally declines when BM increases (Gibb et al., 1996), this implies that an increase in SSH will not be followed to the same extent by an increase in IR. Pasture DMI is the product of GT and IR (Allden and Whit- 


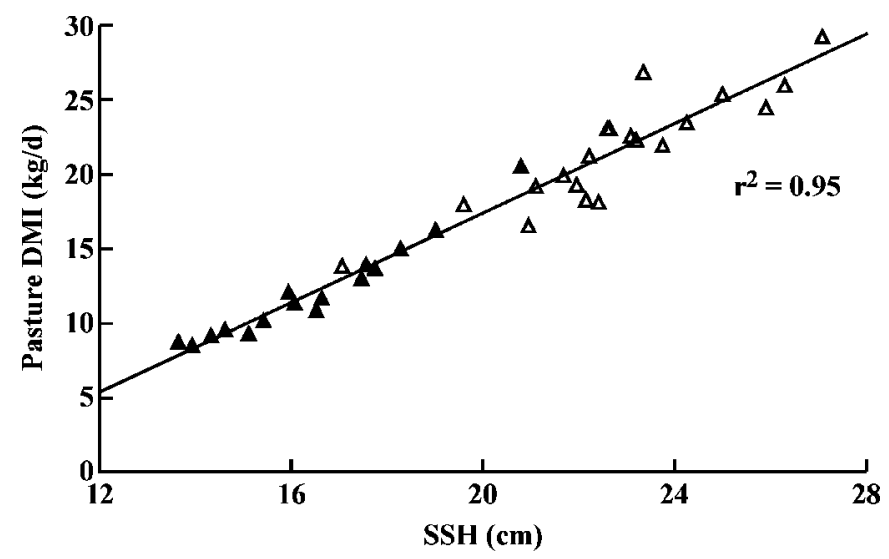

Figure 4. Relation between sward surface height (SSH) and pasture DMI in $1 \mathrm{D}$ ( $\triangle$ rotation $1 ; \boldsymbol{\Delta}$ rotation 2 ). The regression formula is pasture DMI $(\mathrm{kg} / \mathrm{d})=-12.7( \pm 1.2)+1.51( \pm 0.06) \times \mathrm{SSH}(\mathrm{cm})$.

taker, 1970), implying that the cows were able to (partly) compensate IR at shorter SSH by increasing GT. More importantly, from the decrease in SSH between days in $4 \mathrm{D}$ and the relation between $\mathrm{SSH}$ and pasture DMI, it is likely that DMI decreased quadratically between days in $4 \mathrm{D}$. This is confirmed by the curvilinear decrease in milk yield between days in $4 \mathrm{D}$. The maximum milk yield was achieved on the second day of the period followed by a decrease thereafter, indicating that milk yield follows offered pasture with a delay of at least $12 \mathrm{~h}$.

Despite the absence of differences in pasture DMI between treatments, there were differences between both rotations, probably related to SSH. Residual SSH is considered a good indicator for grazing management success, with SSH of 9 to $10 \mathrm{~cm}$ as an indication of efficient grassland management (Virkäjarvi et al., 2002). Le Du et al. (1979) found reduced pasture DMI when residual SSH is below 8 to $10 \mathrm{~cm}$. In the current experiment, there was a difference in residual SSH between both rotations $(10.9 \mathrm{~cm}$ in the first rotation vs. $7.4 \mathrm{~cm}$ in the second rotation; $P<0.001)$. This difference coincided with an interaction between treatment and rotation in pasture DMI $(P=0.025)$ with a $1.8 \mathrm{~kg} / \mathrm{d}$ greater pasture DMI in $1 \mathrm{D}$ than in $4 \mathrm{D}$ in the first rotation, indicating that frequent allocation to a new plot positively affected pasture DMI if offered pasture was sufficient. The lower pasture DMI and SSH in the second rotation was related to a lower BM compared with the first rotation (432 vs. $505 \mathrm{mg}$ of DM/bite, respectively; $P=0.006$ ). The expected increase in $\mathrm{BR}$ due to a decrease in BM (Gibb, 2006) was not seen when comparing both rotations. The greater difference in pasture DMI during the first rotation compared with the second rotation corresponded with a larger difference in FPCM production during the first rotation (4D, 24.3 $\mathrm{kg} / \mathrm{d}$ vs. $1 \mathrm{D}, 25.9 \mathrm{~kg} / \mathrm{d}$ ) than during the second rotation (4D, 21.2 vs. 1D, $21.7 \mathrm{~kg} / \mathrm{d}$ ), although the interaction between treatment and rotation in milk yield was not significant.

\section{Rumen Fermentation and Milk Composition}

Fermentation of NDF results in an increase in acetate and a decrease in propionate production (Bannink et al., 2006). The relation between pasture NDF content and molar proportions of these VFA is demonstrated in the current experiment by the fact that the increase in NDF between 1 and 4 in the 4D treatment (Figure 1) coincided with a strong linear increase in the molar proportion of acetate and a linear decrease in the molar proportion of propionate across days (Table 5). This was also related to milk fat content, although the increase in milk fat content appeared to be delayed by 1 $\mathrm{d}$, showing a peak in milk fat content on $\mathrm{d} 1$ of the $4 \mathrm{D}$ treatment (Table 6). The results also show that changes in milk composition rapidly follow changes in diet composition.

\section{General Treatment Effects}

Between both treatments, pasture DMI and pasture composition were similar. Therefore, production of VFA in the rumen and consequently VFA absorbed from the gastrointestinal tract is assumed to have been rather comparable between $1 \mathrm{D}$ and $4 \mathrm{D}$. Indeed, mean total VFA concentration was similar between treatments, but rumen $\mathrm{pH}$ was lower in $1 \mathrm{D}$ than in $4 \mathrm{D}$. As the fractional rate of absorption of VFA is faster at low rumen $\mathrm{pH}$ (Dijkstra et al., 1993), VFA available for metabolism in the animal may have been greater in 1D than in $4 \mathrm{D}$. This, in combination with the numerical greater pasture DMI of $0.7 \mathrm{~kg}$ of $\mathrm{DM} / \mathrm{d}$ in $1 \mathrm{D}$ might have been the reason for a greater milk and FPCM yield in $1 \mathrm{D}$ than in $4 \mathrm{D}$.

The greater milk fat content in $4 \mathrm{D}$ than in $1 \mathrm{D}$ may be explained by the numerically greater pasture NDF content in $4 \mathrm{D}$, increasing lipogenic nutrients in $4 \mathrm{D}$ as compared with 1D (Bannink et al., 2006). Alternatively, the lower rumen $\mathrm{pH}$ at $1 \mathrm{D}$ may have resulted in incomplete rumen biohydrogenation of pasture linolenic acid and an increased formation of trans fatty acids that inhibit de novo milk fat synthesis in the mammary gland (Baumgard et al., 2002). The concentration of CP in pasture and the concentration of milk urea did not differ between treatments, but the concentration of $\mathrm{NH}_{3}-\mathrm{N}$ in the rumen was greater in $4 \mathrm{D}$ than in $1 \mathrm{D}$. Taking the (numerically) greater pasture DMI in 1D into account, the supply of $\mathrm{CP}$ to cows in this treatment 
was greater than in $4 \mathrm{D}$. The lower rumen $\mathrm{NH}_{3}$ concentration in 1D may be the result of increased microbial protein synthesis. One of the most important factors in microbial efficiency is fractional passage rate (Dijkstra et al., 2002). The numerically greater pasture DMI in $1 \mathrm{D}$, causing greater fractional passage rates of rumen contents, could thus have led to greater microbial protein synthesis in $1 \mathrm{D}$ than in $4 \mathrm{D}$. This is in agreement with greater odd- and branched-chain fatty acid proportion of milk fat from cows in 1D than in 4D (unpublished data), because milk odd- and branched-chain fatty acids are closely related to microbial flow to the duodenum (Vlaeminck et al., 2005).

\section{CONCLUSIONS}

This study confirmed that increased pasture allocation frequency from once every $4 \mathrm{~d}$ to once a day improved milk production in grazing dairy cows, especially when the amount of pasture offered was high. This was mainly the result of a change in grazing behavior, resulting in an increase in pasture DMI.

\section{ACKNOWLEDGMENTS}

Bruno Vlaeminck is a postdoctoral fellow of the Fund for Scientific Research-Flanders (Belgium). The authors thank the personnel of the experimental farm De Ossekampen for their assistance. The students involved in this experiment, A. Kidane Sagaye, D. Reynaud, and I. Jorna, are especially acknowledged for their help during the experiment. The financial support from the Product Board Animal Feed (PDV) and the Dutch Dairy Board (PZ) is greatly acknowledged.

\section{REFERENCES}

Albright, J. L. 1993. Feeding behavior of dairy cattle. J. Dairy Sci. 76:485-498.

Allden, W. G., and I. A. McD. Whittaker. 1970. The determinants of herbage intake by grazing sheep: The interrelationship of factors influencing herbage intake and availability. Aust. J. Agric. Res. 21:755-766.

Bannink, A., J. Kogut, J. Dijkstra, J. France, E. Kebreab, A. M. Van Vuuren, and S. Tamminga. 2006. Estimation of the stoichiometry of volatile fatty acid production in the rumen of lactating cows. J. Theor. Biol. 238:36-51.

Bargo, F., L. D. Muller, J. E. Delahoy, and E. S. Kolver. 2003. Invited review: Production and digestion of supplemented dairy cows on pasture. J. Dairy Sci. 86:1-42.

Baumgard, L. H., E. Matitashvili, B. A. Corl, D. A. Dwyer, and D. E. Bauman. 2002. Trans-10, cis-12 conjugated linoleic acid decreases lipogenic rates and expression of genes involved in milk lipid synthesis in dairy cows. J. Dairy Sci. 85:2155-2163.

Chilibroste, P. 2005. Pasture characteristics and animal performance. Pages 681-706 in Quantitative Aspects of Ruminant Digestion and Metabolism. J. Dijkstra, J. M. Forbes, and J. France, ed. CAB International, Wallingford, UK.

Chilibroste, P., S. Tamminga, H. Boer, M. J. Gibb, and G. den Dikken. 2000. Duration of regrowth of ryegrass (Lolium perenne) effects on grazing behavior, intake, rumen fill, and fermentation of lactating dairy cows. J. Dairy Sci. 83:984-995.

CVB. 2007. Tabellenboek Veevoeding 2000 (Dutch Feeding Tables). Voedernormen landbouwhuisdieren en voederwaarde veevoeders (in Dutch). Central Bureau for Livestock Feeding, Lelystad, the Netherlands.

Dalley, D. E., J. R. Roche, P. J. Moate, and C. Grainger. 2001. More frequent allocation of herbage does not improve the milk production of dairy cows in early lactation. Aust. J. Exp. Agric. 41:593-599.

Delagarde, R., J. L. Peyraud, L. Delaby, and P. Faverdin. 2000. Vertical distribution of biomass, chemical composition and pepsincellulase digestibility in a perennial ryegrass sward: Interaction with month of year, regrowth age and time of day. Anim. Feed Sci. Technol. 84:49-68.

Dijkstra, J., H. Boer, J. Van Bruchem, M. Bruining, and S. Tamminga. 1993. Absorption of volatile fatty acids from the rumen of lactating dairy cows as influenced by volatile fatty acid concentration, $\mathrm{pH}$ and rumen liquid volume. Br. J. Nutr. 69:385-396.

Dijkstra, J., J. A. N. Mills, and J. France. 2002. The role of dynamic modelling in understanding the microbial contribution to rumen function. Nutr. Res. Rev. 15:67-90.

Dove, H., and R. W. Mayes. 1991. The use of plant wax alkanes as marker substances in studies of the nutrition of herbivores: A review. Aust. J. Agric. Res. 42:913-952.

Forbes, J. M. 1996. Integration of regulatory signals controlling forage intake in ruminants. J. Anim. Sci. 74:3029-3035.

Gibb, M. J. 2006. Grassland management with emphasis on grazing behaviour. Pages 141-157 in Fresh Herbage for Dairy Cattle. A. Elgersma, J. Dijkstra and S. Tamminga, ed. Springer, the Netherlands.

Gibb, M. J., C. A. Huckle, R. Nuthall, and P. D. Penning. 1996. Can grazed pasture meet the needs of the high genetic merit dairy cow? In Grass and Forage for Cattle of High Genetic Merit. Proc. Br. Grassl. Soc., Reading, UK.

Gibb, M. J., C. A. Huckle, R. Nuthall, and A. J. Rook. 1997. Effect of sward surface height on intake and grazing behaviour by lactating Holstein Friesian cows. Grass Forage Sci. 52:309-321.

Goelema, J. O., M. A. M. Spreeuwenberg, G. Hof, A. F. B. van der Poel, and S. Tamminga. 1998. Effect of pressure toasting on the rumen degradability and intestinal digestibility of whole and broken peas, lupins and faba beans and a mixture of these feedstuffs. Anim. Feed Sci. Technol. 76:35-50.

Holecheck, J. L., R. D. Pieper, and C. H. Herbel. 1995. Range management: Principles and Practices. 2nd ed. Prentice Hall, Englewood Cliffs, NJ.

Illius, A. W., and I. J. Gordon. 1987. The allometry of food intake in grazing ruminants. J. Anim. Ecol. 56:989-999.

ISO. 1997. Animal Feeding Stuffs. Determination of nitrogen content and calculation of crude protein content-Kjeldahl method. ISO 5983:1997. International Organization for Standardization, Geneva, Switzerland.

ISO. 1999a. Animal Feeding Stuffs. Determination of moisture and other volatile matter content. ISO 6496:1999. International Organization for Standardization, Geneva, Switzerland.

ISO. 1999b. Animal Feeding Stuffs. Determination of fat content. ISO 6492:1999. International Organization for Standardization, Geneva, Switzerland.

ISO. 1999c. Whole milk. Determination of milkfat, protein and lactose content-Guidance on the opoeration of mid-infrared instruments. ISO 9622:1999. International Organization for Standardization, Geneva, Switzerland.

ISO. 2002. Animal Feeding Stuffs. Determination of crude ash. ISO 5984:2002. International Organization for Standardization, Geneva, Switzerland.

ISO. 2004. Milk. Determination of urea content-Enzymatic method using difference in $\mathrm{pH}$ (Reference method). ISO 14637:2004. International Organization for Standardization, Geneva, Switzerland.

Kuusela, E., and H. Khalili. 2002. Effect of grazing method and herbage allowance on the grazing efficiency of milk production in organic farming. Anim. Feed Sci. Technol. 98:87-101. 
Le Du, Y. L. P., J. Combellas, J. Hodgson, and R. D. Baker. 1979. Herbage intake and milk production by grazing dairy cows 2 . The effects of level of winter feeding and daily herbage allowance. Grass Forage Sci. 34:249-260.

Littell, R. C., P. R. Henry, and C. B. Ammerman. 1998. Statistical analysis of repeated measures data using SAS procedures. J. Anim. Sci. 76:1216-1231.

Miller, L. A., J. M. Moorby, D. R. Davies, M. O. Humphreys, N. D. Scollan, J. C. MacRae, and M. K. Theodorou. 2001. Increased concentration of water-soluble carbohydrate in perennial ryegrass (Lolium perenne L.): Milk production from late-lactation dairy cows. Grass Forage Sci. 56:383-394.

Moorby, J. M., R. T. Evans, N. D. Scollan, J. C. MacRae, and M. K. Theodorou. 2006. Increased concentration of water-soluble carbohydrate in perennial ryegrass (Lolium perenne L.). Evaluation in dairy cows in early lactation. Grass Forage Sci. 61:52-59.

Orr, R. J., S. M. Rutter, P. D. Penning, and A. J. Rook. 2001. Matching grass supply to grazing patterns for dairy cows. Grass Forage Sci. 56:352-361.

Parsons, A. J., and D. F. Chapman. 2000. The principles of pasture growth and utilisation. Pages 31-89 in Grass, Its Production and Utilisation. A. Hopkins, ed. Blackwell Science, Oxford, UK.

Rutter, S. M. 2000. Graze: A program to analyze recordings of the jaw movements of ruminants. Behav. Res. Methods Instrum. Comput. 32:86-92.

Rutter, S. M. 2006. Diet preference for grass and legumes in freeranging domestic sheep and cattle: Current theory and future application. Appl. Anim. Behav. Sci. 97:17-35.

Rutter, S. M., R. A. Champion, and P. D. Penning. 1997. An automatic system to record foraging behaviour in free-ranging ruminants. Appl. Anim. Behav. Sci. 54:185-195.

Tamminga, S., W. M. van Straalen, A. P. J. Subnel, R. G. M. Meijer, A. Steg, C. J. G. Wever, and M. C. Blok. 1994. The Dutch protein evaluation system: The DVE/OEB-system. Livest. Prod. Sci. 40:139-155.

Tas, B. M., H. Z. Taweel, H. J. Smit, A. Elgersma, J. Dijkstra, and S. Tamminga. 2006. Effects of perennial ryegrass cultivars on milk yield and nitrogen utilization in grazing dairy cows. J. Dairy Sci. 89:3494-3500.

Taweel, H. Z., B. M. Tas, J. Dijkstra, and S. Tamminga. 2004. Intake regulation and grazing behavior of dairy cows under continuous stocking. J. Dairy Sci. 87:3417-3427.

Taweel, H. Z., B. M. Tas, H. J. Smit, A. Elgersma, J. Dijkstra, and S. Tamminga. 2005. Effects of feeding perennial ryegrass with an elevated concentration of water-soluble carbohydrates on intake, rumen function and performance of dairy cows. Anim. Feed Sci. Technol. 121:243-256.

Taweel, H. Z., B. M. Tas, H. J. Smit, A. Elgersma, J. Dijkstra, and S. Tamminga. 2006. Grazing behaviour, intake, rumen function and milk production of dairy cows offered Lolium perenne containing different levels of water-soluble carbohydrates. Livest. Sci. 102:33-41.

Van Es, A. J. H. 1975. Feed evaluation for dairy cows. Livest. Prod. Sci. 2:95-107.

Van Soest, P. J. 1973. Collaborative study of acid-detergent fibre and lignin. J. Assoc. Off. Anal. Chem. 56:781-784.

Van Soest, P. J., J. B. Robertson, and B. A. Lewis. 1991. Methods for dietary fiber, neutral detergent fiber, and nonstarch polysaccharides in relation to animal nutrition. J. Dairy Sci. 74:35833597.

Van Vuuren, A. M., C. J. Van Der Koelen, H. Valk, and H. De Visser. 1993. Effects of partial replacement of ryegrass by low protein feeds on rumen fermentation and nitrogen loss by dairy cows. J. Dairy Sci. 76:2982-2993.

Virkäjarvi, P., A. Sairanen, J. I. Nousiainen, and H. Khalili. 2002. Effect of herbage allowance on pasture utilization, regrowth and milk yield of dairy cows in early, mid and late season. Anim. Feed Sci. Technol. 97:23-40.

Vlaeminck, B., C. Dufour, A. M. van Vuuren, A. R. J. Cabrita, R. J. Dewhurst, D. Demeyer, and V. Fievez. 2005. Use of odd and branched-chain fatty acids in rumen contents and milk as a potential microbial marker. J. Dairy Sci. 88:1031-1042.

Wales, W. J., P. T. Doyle, and D. W. Dellow. 1998. Dry matter intake and nutrient selection by lactating cows grazing irrigated pastures at different pasture allowances in summer and autumn. Aust. J. Exp. Agric. 38:451-460. 